\title{
BAZALTİK KAYAÇLARIN BALAST KİRLENMESİ YÖNÜNDEN KARŞILAŞTIRILMASI
}

\author{
Ömer Faruk APAYDIN ${ }^{1}$ (ORCID: 0000-0003-1594-7646) \\ Murat YILMAZ ${ }^{2}$ (ORCID: 0000-0002-9598-1408) ${ }^{*}$ \\ ${ }^{1}$ Büyükçekmece Belediyesi, Fen Işsleri Müdürlüğü, Fatih Mah., Şehremini Sk. No:1, Istanbul, Türkiye \\ ${ }^{2}$ Istanbul Üniversitesi-Cerrahpaşa, Mühendislik Fakültesi, Jeoloji Mühendisliği Bölümü, İstanbul, Türkiye
}

Gelis / Received: 29.08 .2018 Kabul / Accepted: 28.11.2018

\begin{abstract}
ÖZ
Günümüzde artan ulaşım talebi nedeniyle, yüksek hızlı demiryolu projelerine ihtiyaç artmaktadır. Demiryolu ulaşım teknolojisinde trenlerin çok yüksek süratlere çıkması, demiryollarına serilen balast agregalarını daha yüksek dinamik gerilmelere maruz bırakmaktadır. Bundan dolayı, agregaların dayanım ve dayanıklılığının istenilen düzeyde olması ve balast kirlenmesine neden olmaması gerekmektedir. Bu çalışmada farklı özelliklere sahip bazaltik kayaçların balast agregası olarak kullanılabilirliklerinin karşılaştırılması ve bu kayaçların bileşim ve dokularının balast kirlenmesi üzerindeki etkilerinin nedenleriyle birlikte ortaya konulması amaçlanmıştır. Araştırmalar örnek çeşitliliğgi sağlamak amacıyla, Türkiye'nin farklı bölgelerinde bulunan bazalt ocaklarından alınmış balast örnekleri üzerinde gerçekleştirilmiştir. Bazaltik kayaçların öncelikle mineralojik, petrografik ve kimyasal özellikleri belirlenmiştir. Daha sonra bu ocaklardan getirilen agregaların dayanım ve dayanıklılık özelliklerini belirlemek amacıyla standart agrega deneyleri yapılmıştır. Bazaltik kayaç agregaları üzerinde gerek tren yüklerinin oluşturacağı dinamik yüklerin, gerekse de iklimsel koşulların (donma-çözünme) balast kirlenmesine etkilerini ortaya koymak için farklı devir sayılarında Los Angeles aşınma testleri ve magnezyum sülfat testleri yapılmıştır. Ayrıca bu çalışma kapsamında, bazaltik kayaçların mineral bileşimleri dikkate alınarak yeni bir petrografik indeks tanımlaması yapılmıştır. Elde edilen sonuçlara göre, bu petrografik indeks ve daha önceki çalışmalarda tanımlanmış kimyasal indeksler, bazalt kirlenmesini değerlendirmek için önemli parametreler olarak belirlenmiştir. Özellikle kimyasal indekslerden Vogt oranı, diğer indekslere göre daha iyi sonuçlar sunmuştur. Bunun dışında yüksek dayanıma sahip ayrışmamış veya az ayrışmış olan bazaltik agregalar, servis ömürleri süresince balast kirlenmesine neden olmayacakları belirlenmiştir.
\end{abstract}

Anahtar Sözcükler: Bazaltik kayaç, balast agregası, balast kirlenmesi

\section{COMPARISON OF BASALTIC ROCKS FROM THE POINT OF BALLAST FOULING}

\begin{abstract}
The need for high-speed rail projects is increasing with today's increasing demand for transportation. The high speeds of trains in railway transportation technology expose the ballast aggregates laid on the railways to higher dynamic stresses. Therefore, it is necessary that the strength and durability of the aggregates are at the desired level and do not cause ballast fouling. In this study, it is aimed to compare the usability of basaltic rocks with
\end{abstract}

${ }^{*}$ Corresponding author / Sorumlu yazar Tel.: +90 212 4737070; e-mail/e-posta: yilmazm @istanbul.edu.tr 
different properties as ballast aggregates and to combine the composition and texture of these rocks with the effects of ballast contamination. The investigations have been carried out on ballast samples taken from basalt quarries located in different regions of Turkey in order to provide sample diversity. Mineralogical, petrographical and chemical properties of basaltic rocks are determined primarily. Standard aggregate tests were then carried out to determine the strength and durability properties of the aggregates brought from the quarries. Los Angeles tests and magnesium sulphate tests were performed at different speeds to demonstrate the effects of dynamic loads on the basaltic rock aggregates, as well as climatic conditions (freeze-thaw) caused by train loads. In addition, a new petrographic index was defined by considering the mineral composition of basaltic rocks. According to the results obtained, this petrographic index and chemical indexes, which were defined in previous studies, for basaltic aggregates were identified as important parameters for evaluating the causes of basalt fouling. Especially, it is determined that the Vogt ratio among chemical indexes gave much better results. Beside this, it is determined that the unaltered or slightly altered basaltic aggregates show high resistance during the service life and cause ballast fouling.

Keywords: Ballast fouling, basalt aggregate, petrographic index, Los Angeles test

\section{GİRIŞ}

Özellikle nüfus artışına paralel olarak şehirleşme ve buna bağlı bina, demiryolu, metro, yol, köprü gibi yapıların önem kazanmasının yanı sıra, gelişen endüstri nedeniyle artan enerji ihtiyacı ve buna bağlı olarak büyük baraj ve su yapılarının artması nedeniyle, bu yapıların temel yapı malzemesi olan agregaların önemi de artmaktadır. Öte yandan, ülkemizde demiryolları geçmişten günümüze ulaşım sistemleri içerisinde önemli bir yere sahiptir. Gelişen teknolojiye bağlı olarak artan hız ve yük taşıma kapasitesi, demiryollarının verimini arttırmakta, dolayısıyla demiryollarına yapılan yatırımlar giderek artmakta ve böylece demiryolu yapımı sırasında kullanılan hammaddelerin miktarında da her geçen gün artışlar meydana gelmektedir.

Demiryolu yapımında ana malzemelerden biri olan ve yüksek oranda kullanılan agregaların niteliği, demiryolu projelerinin yaygınlaştığı günümüzde oldukça önemli bir rol oynamaktadır. Demiryolu agregaları ve balast kirliliği üzerine günümüze kadar yapılan fazla bir çalışma bulunmamaktadır. Arığlu vd. [1], çalışmalarında farklı kökenli kayaçların yüksek devirde Los Angeles aşınma değerlerini hesaplamışlardır. Çalışma sonucunda bazalt ve amfibolitlerin kuru ve suya doygun durumdaki aşıma değerlerinin diğer kayaçlara göre biraz daha düşük olduğunu belirtmişlerdir. McNally [2] ise, demiryolu balastlarında aranılan özellikler ile balastlar üzerinde yapılan dayanım ve dayanıklılık testlerini araştırmıştır. Ayrıca, hangi tip kayaçların balast agregası olarak kullanılabileceğini nedenleri ile birlikte belirtmiştir. Balast kirliliği üzerine ise Schilling [3], tren yüklerinden ve iklimsel faktörlerden dolayı meydana gelen ve demiryollarının servis ömürlerinin azalmasına neden olan problemlerin (balast kirlenmesi gibi) tespitinde track-bound teknolojilerinin kullanılabileceğini belirtmiştir. Ayrıca Roberts vd. [4], demiryollarında karşılaşılan ve en önemli sorunlardan biri olan balast kirlenmesini yer radarı (GPR) yöntem ile incelemişlerdir. Çalışma sonucunda, demiryollarının rutin servis bakımlarında balast kirlenmesini belirlemek için GPR yönteminin kullanılabileceğini saptamışlardır. Yüksek hızlı trenler ile oluşan güçlü rüzgârların balastları yerinden oynattıklarını ve bu oynamada tren hızının, balastın yoğunluğunun ve şeklinin önemli etkenler olduğunu ayrıca, balast kirlenmesini arttırdığı da belirlenmiştir [5].

Tren yüklerinden kaynaklanan dinamik yükler ve iklim koşullarına bağlı olarak gelişen balast kirlenmesi, raylı sistemlerde, servis ömrü süresince karşılaşılan en önemli problemlerden biridir. Bu problemin balast agregalarının hangi özelliklerinden kaynaklandığı detaylı olarak araştırılmamıştır. Bu sorunun nedenlerinin belirlenmesi ve farklı özellikteki bazaltik kayaçların öncelikle bu açıdan kıyaslanmaları bu çalışmanın ana amaçlarından biridir. Balast kirlenmesinin nedenleri araştırılırken öncelikle agregaların mineralojik, petrografik ve kimyasal özellikleri belirlenmiştir. Bazaltik kayaçların mineralojik bileşimlerine göre yeni bir petrografik indeks tanımlanması yapılmıştır. Ayrıca incelenen kayaçlar diğer agrega özellikleri açısından da karşılaştırılmıştır. Bazaltik kayaç agregalarının balast agregası olarak demiryollarında kullanılmaları durumunda, tren yüklerinden kaynaklanan dinamik yüklerin balast kirlenmesine etkilerini belirlemek amaciyla ilgili agregalar üzerinde farklı devir sayılarında (1000, 2000, 3000 devir) Los Angeles testleri yapılmış ve her bir deney sonrası agregaların bünyesinde gelişen mikro çatlak özellikleri belirlenmiştir. Bunun dışında, iklimsel koşulların neden 
olduğu donma çözünmenin balast kirlenmesi üzerine etkilerini belirlemek için bazaltik kayaç agregaları üzerinde magnezyum sülfat testleri yapılmıştır. Magnezyum sülfat testleri, ilgili agregalara başlangıçta (saha çalışmalarından getirilen balast agregaları) ve 3000 devir Los Angeles cihazında yıpratıldıktan/ufalandıktan sonra yapılmıştır. Her bir magnezyum sülfat testi sonrası agregalardan ince kesitler hazırlanıp ve bunlar üzerinde gelişen mikro çatlak özellikleri belirlenmiştir.

\subsection{Bazalt Agregasının Temini}

Araştırmalar için Türkiye'nin çeşitli bölgelerinde bulunan farklı özelliklere sahip bazaltik kayaçlar seçilmiştir. Bazaltik kayaçların seçildiği bölgeler Şekil 1 üzerinde verilmiştir. Günümüzde bu kayaçların dayanım ve dayanıklılıklarını konu alan çalışmalar bulunmakta $[6,7]$ ve bu özellikleri nedeniyle ülkemizde balast agregası olarak tercih edilmektedir. Ancak farklı doku ve bileşime sahip olabilen bu kayaçların balast kirlenmesi üzerine etkilerini konu alan gerek ülkemizde gerekse de dünyada bu kadar kapsamlı bir araştırma yapılmamıştır.

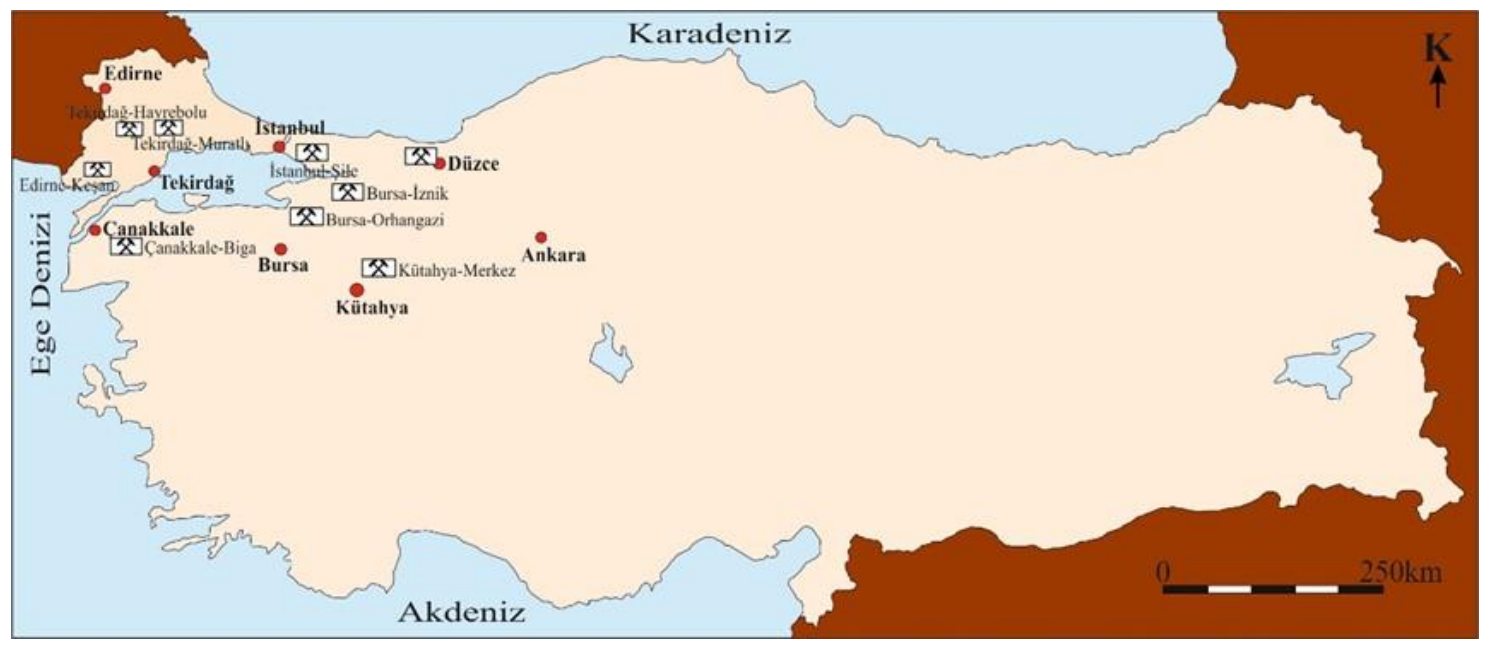

Şekil 1. İncelenen bazaltik kayaçların alındığı ocak yerlerini gösteren yer bulduru haritası

\subsection{Balast Kirlenmesi}

Demiryollarında kullanılan balast agregalarının en önemli görevlerinden biri, agregalar arasında geniş boşluklar bulunmasından dolayı birikebilecek suyun drenajını sağlamaktır. Ancak zaman içinde artan dinamik yükler (tren yükleri) ve iklim koşulları (donma-çözünme) agregaların parçalanmasına ve oluşan ufak parçacıkların agregaların aralarındaki boşluklara yerleşmesine neden olmaktadır (Şekil 2 ve Şekil 3). Bu durum boşluklar aracılığıyla tahliye edilmesi gereken suyun demiryolunun içerisinde kalmasıyla sonuçlanmaktadır. Demiryolu bünyesinde kalan sular ise, balast agregalarının dayanım ve dayanıklılıklarını azaltmakta ve böylece demiryolu zarar görmektedir. Bu olaya balast kirlenmesi adı verilmektedir. 


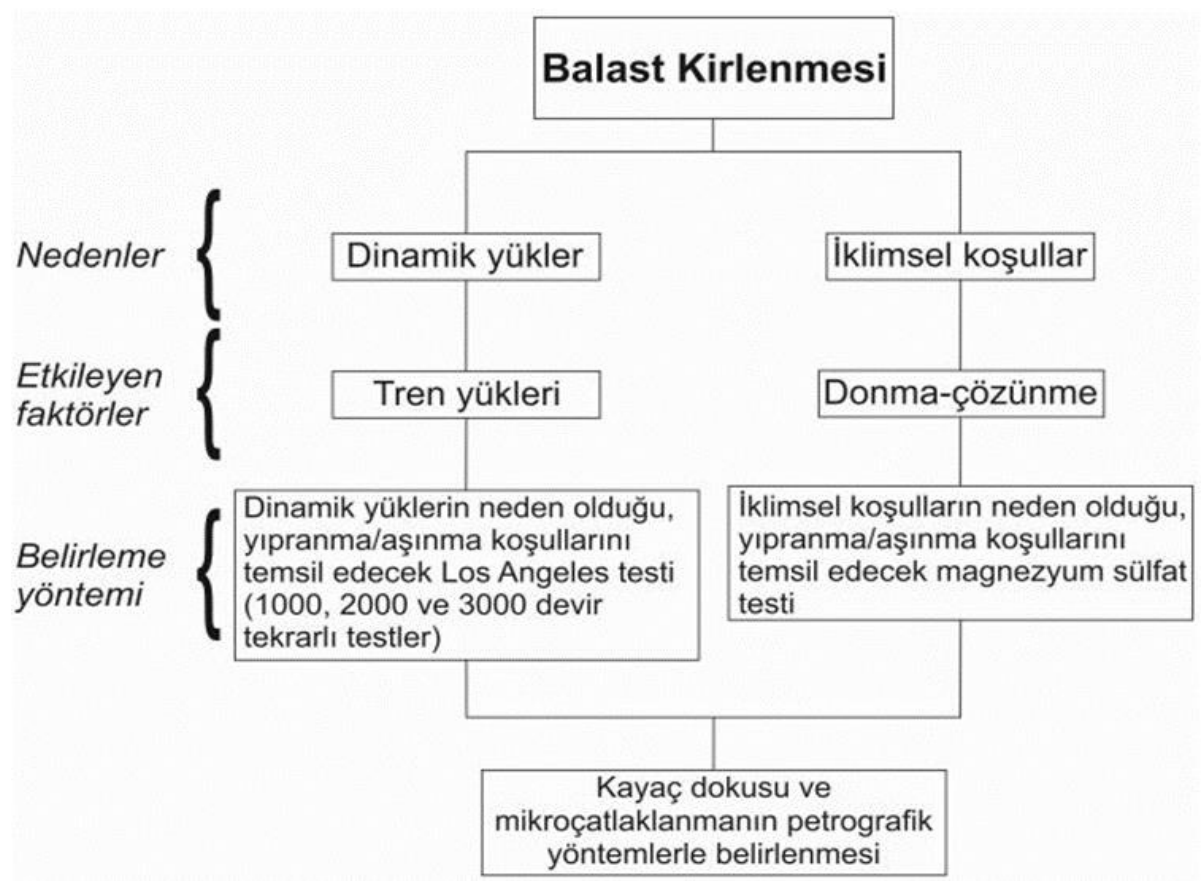

Şekil 2. Balast kirlenmesine neden olan faktörler ve belirleme yöntemleri

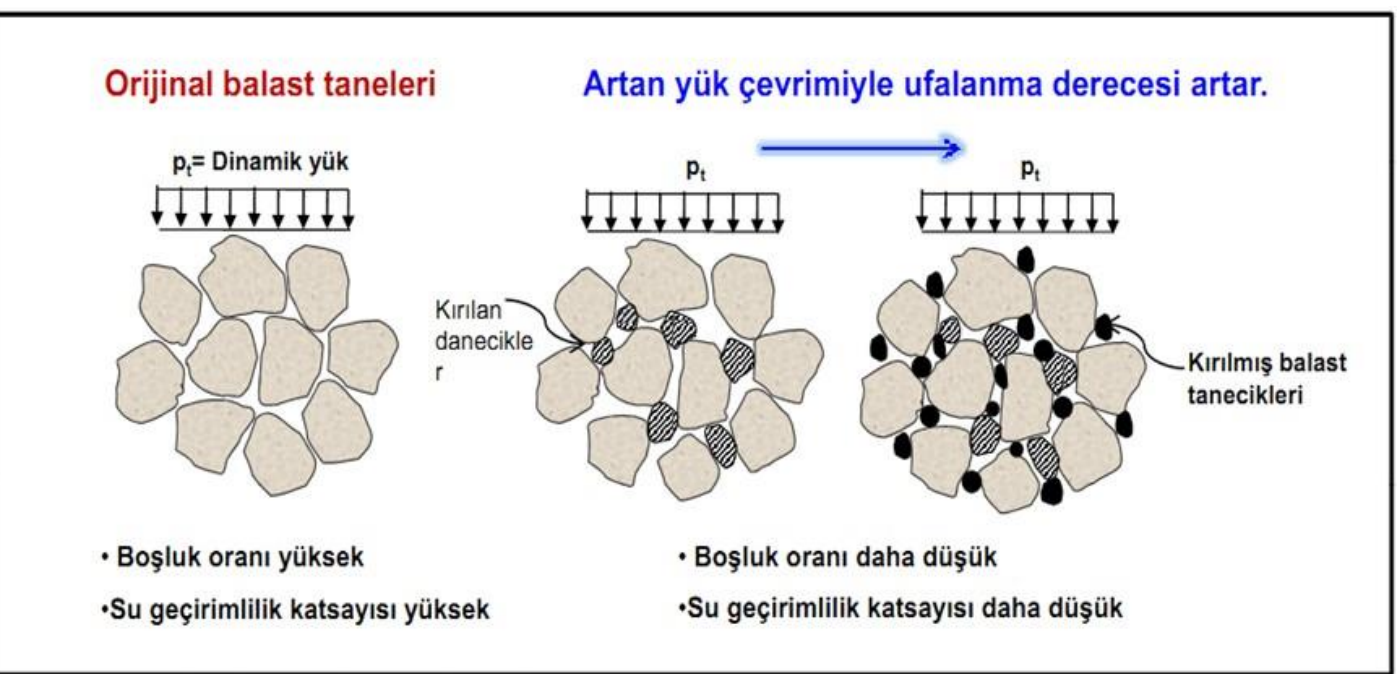

( $p_{t}=$ Travers altındaki dinamik basınç gerilmesi)

Şekil 3. Zaman içerisinde artan dinamik yükler ve çevre koşularına bağlı meydana gelen balast kirlenmesi [1]

Balast kirlenmesinin en önemli birinci nedeni, agrega taneciklerinin kırılmasıdır. Balast tabakası altında bulunan, subbalast veya alt temel tabakalarından ince malzemelerin, balast tabakası içerisine nüfuz etmesi ise ikincil balast kirlenmesi olarak bilinmektedir. Çevreden, balast içerisine giren toz miktarı ise tahmin edildiğinden daha az etkiye sahiptir. Ancak, hat üzerinde, maden cevheri, kömür ve kum gibi malzemelerin taşınması durumunda, bu oranın artacağı bilinmektedir [8], (Şekil 4). 


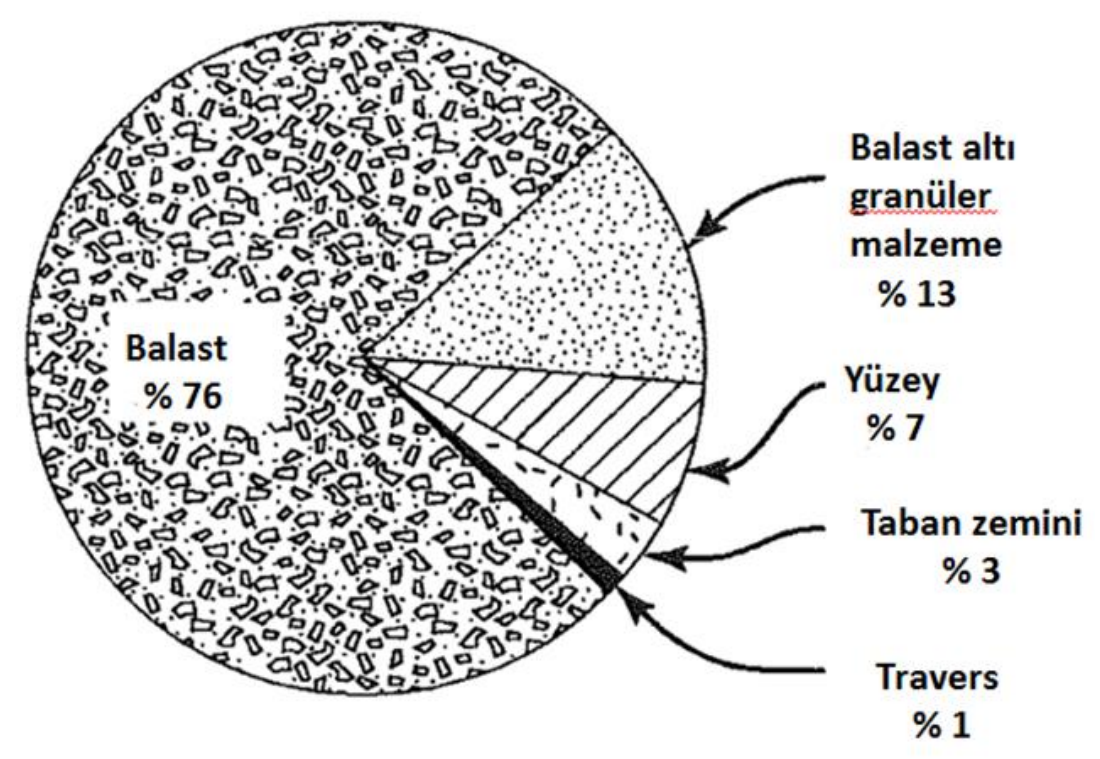

Şekil 4. Balast kirlenme nedenleri [8]

\section{MATERYAL VE METOT}

Bazaltlar kimyasal ve mineralojik bileşimleri bakımından gabronun volkanik karşıtlarıdır. Bazaltlar basit olarak mineralojik bileşimlerine dayanılarak olivin içeren ve olivin içermeyen bazaltlar şekilden iki gruba ayrılırlar. Bu özelliğin silis ve Fe-Mg içeriğine bağlı olarak ortaya çıktığı ifade edilebilir [9].

Demiryolu ulaşımında balast agregası olarak kullanılması düşünülen bazaltik kayaçların, mineralojik ve petrografik özelliklerinin detaylı bir şekilde tanımlanması son derece önemlidir. Bu çalışmada; bazaltik kayaçların mineralojik ve petrografik özellikleri, kayacın fiziksel ve mekanik özelliklerini etkilemesinden dolayı, ayrıntılı olarak tanımlanmıştır. Ayrıca, donma ve çözünmenin iklim koşullarına bağlı olarak kayaçta meydana getirdiği parçalanma etkileşimi önemli oranda etkilediği için de, bazaltik kayaçların mineralojik ve petrografik özellikleri ayrıntılı bir biçimde tanımlanmaya çalışılmıştır. Bu kapsamda Türkiye'nin çeşitli bölgelerinden alınan bazaltik kayaçlardan öncelikle ince kesitler hazırlanmıştır. Bu ince kesitler üzerinde kayacın mineral ve hamur içeriği, dokusu, hamur özellikleri, ayrışma durumları ve mineralojik bileşimlerine göre sınıflandırılmaları yapılmıştır. Elde edilen sonuçlar Tablo 1 ve Şekil 5'de sunulmuştur.

İnce kesitler üzerinde bazaltik kayaçların mineralojik bileşimini kantitatif olarak belirlemek için modal analizler yapılmıştır. Modal analiz için her bir bazalt kesiti üzerinde 2000 nokta sayımı gerçekleştirilmiştir. Elde edilen sonuçlar Tablo 2'de sunulmuştur.

Bazaltik kayaçların kimyasal özelliklerini belirlemek amacıyla çalışma kapsamında kullanılan örnekler laboratuvar ortamında ögütülerek toz haline getirilmiş ve bu örnekler üzerinde XRF yöntemine göre analizler yapılmıştır. Analiz sonucunda bazaltik kayaçların bileşimlerinde bulunan ana element oksit yüzdeleri belirlenmiştir (Tablo 3).

Bazaltik kayaçların agrega özelliklerini belirlemek amacıyla TS EN 13450 (2004)'de belirtilen, tane büyüklüğü dağılımı, ince malzeme ve çok ince malzeme içeriği, yassılık endeksi, tane uzunluğu, tane yoğunluğu, su emme, Los Angeles, Micro Deval ve magnezyum sülfat $\left(\mathrm{MgSO}_{4}\right)$ deneyleri yapılmıştır. Bu kapsamda yapılan deneyler üç kez tekrar edilmiş olup, elde edilen sonuçların ortalaması alınmıştır. Ayrıca, kayaçların tek eksenli basınç dayanımları agrega tanelerinin dayanımları hakkında önemli fikirler sağladığından, tek eksenli basınç dayanımı deneyi de yapılmıştır. Bu deney arazi çalışmalarından getirilen blok numunelerden laboratuvar tipi karot makinesi yardımı ile karotlar alınarak yapılmıştır. Deneyler TS EN standartlarındaki belirtilen şartlara uygun olarak yapılmıştır (Tablo 4). Bazaltik kayaç agregalarına ait deneylerden elde edilen sonuçlar ise Tablo 5, 6 ve 7'de verilmiştir. Bunun dışında çalışma kapsamında Los Angeles aşınma deneyi ilksel, 1000, 2000 ve 3000 
devirlerde uygulanmış ve her bir devir sonunda bazalt agregalarına ait mikro çatlak özellikleri saptanmıştır. Magnezyum sülfat testi bazaltik kayaç agregaları üzerinde başlangıçta (ilksel) ve 3000 devir Los Angeles test cihazında çevrilip yıpratıldıktan/aşındırıldıktan sonra yapılmış ve bu testler sonucunda ilgili agregalardan ince kesitler hazırlanıp mikro çatlak özellikleri belirlenmiştir. Elde edilen sonuçlar Tablo 8, 9 ve 10 da sunulmuştur.

\begin{tabular}{|c|c|c|c|c|c|c|c|c|c|}
\hline 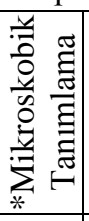 & $\begin{array}{l}\text { Еี } \\
\text { స్ } \\
\text { صิ }\end{array}$ & 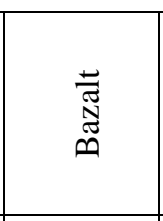 & 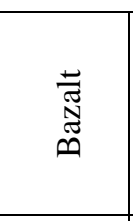 & 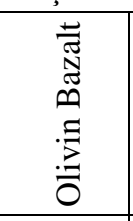 & 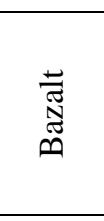 & 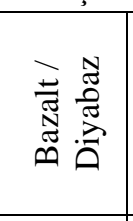 & 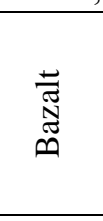 & $\begin{array}{l}\overrightarrow{0} \\
\stackrel{\vec{\partial}}{\circ}\end{array}$ & 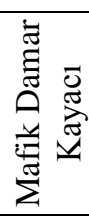 \\
\hline 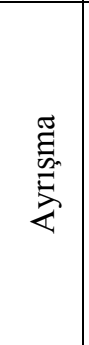 & 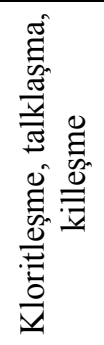 & 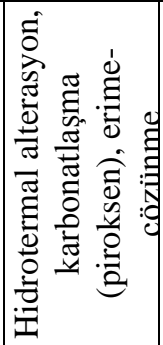 & 更 & 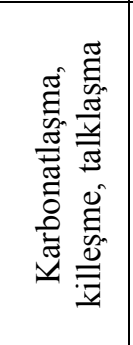 & 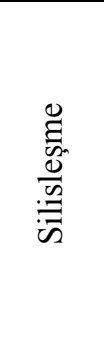 & 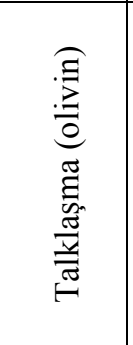 & ' & 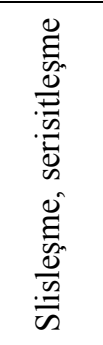 & 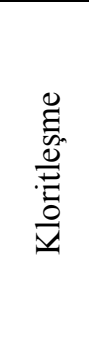 \\
\hline 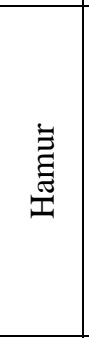 & 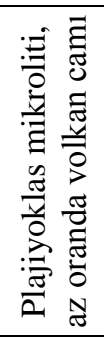 & 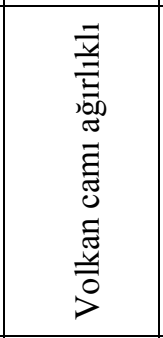 & 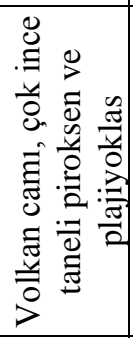 & 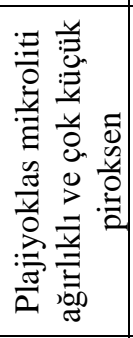 & 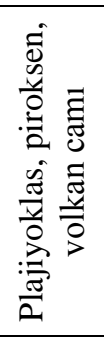 & 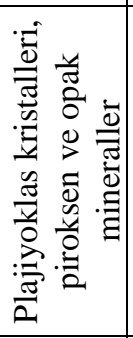 & 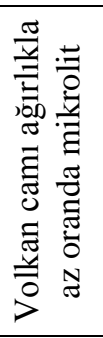 & & \\
\hline$\frac{\vec{z}}{0}$ & 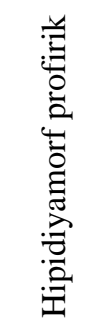 & 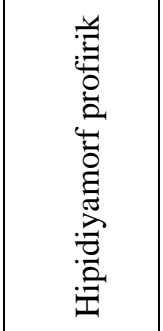 & 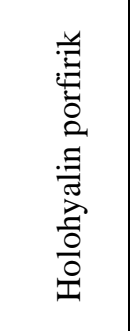 & 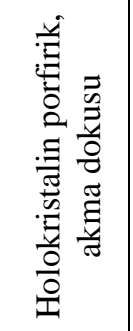 & 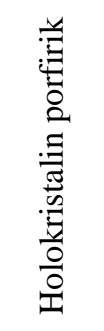 & 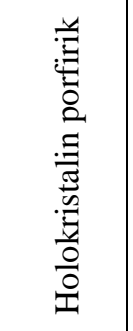 & 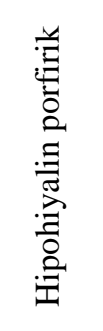 & 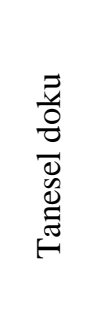 & 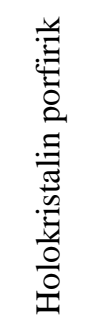 \\
\hline 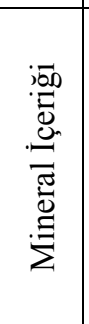 & 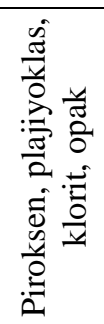 & 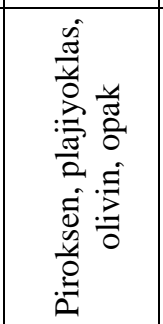 & 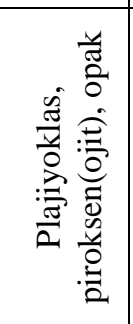 & 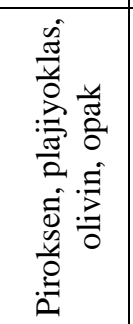 & 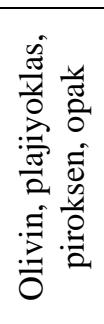 & 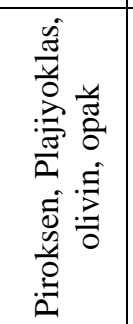 & 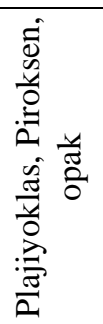 & 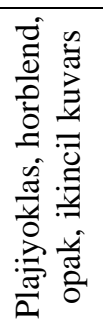 & 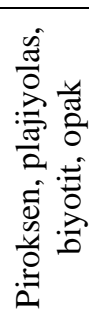 \\
\hline 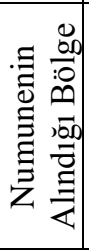 & 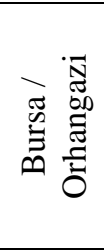 & 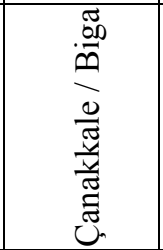 & 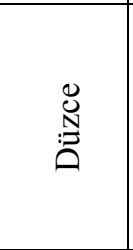 & 莺 & 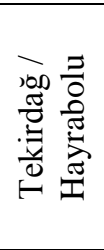 & 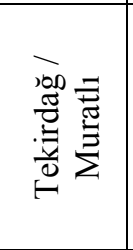 & 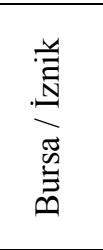 & 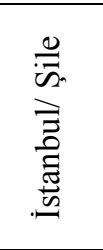 & 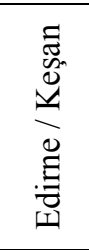 \\
\hline 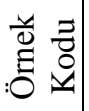 & $\stackrel{\infty}{\infty}$ & en & คิ & $\frac{v}{\infty}$ & $\underset{⿱ 丷}{\stackrel{D}{\mid c}}$ & $\underset{\infty}{\sum_{\infty}}$ & $\vec{m}$ & $\vec{n}$ & $\frac{1}{\infty}$ \\
\hline
\end{tabular}




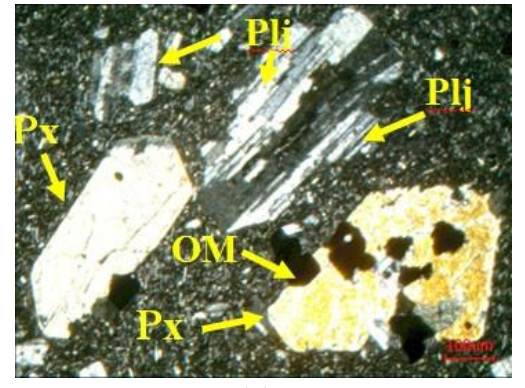

(a)

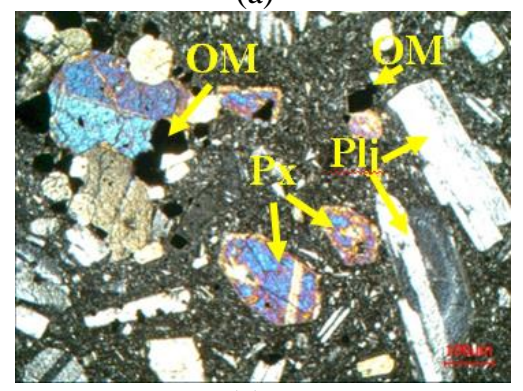

(c)

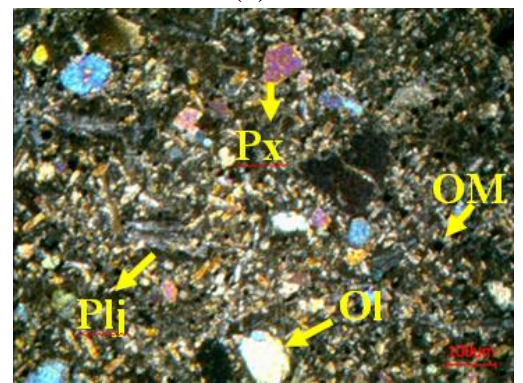

(e)

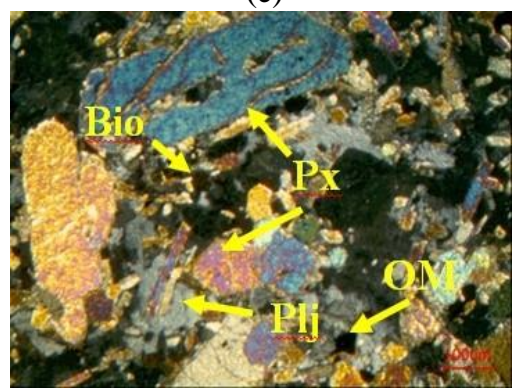

(g)

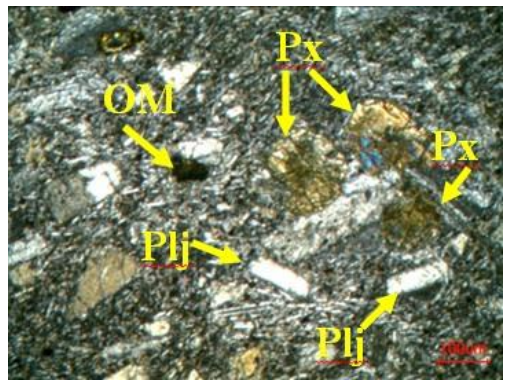

(b)

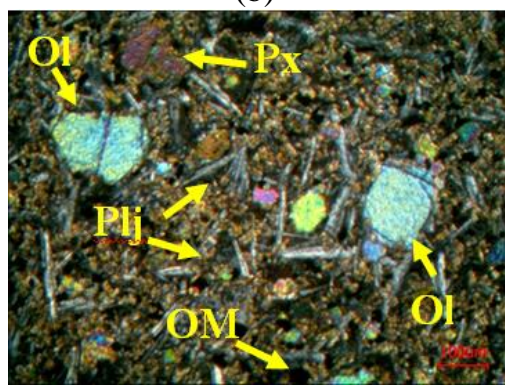

(d)

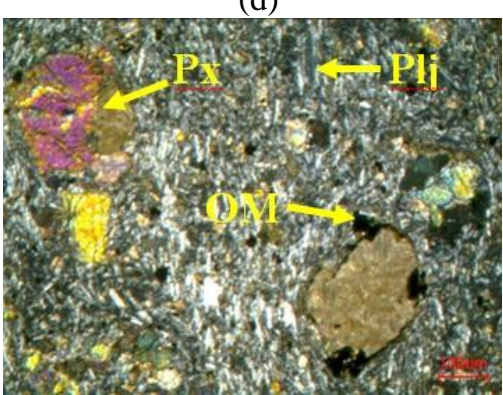

(f)

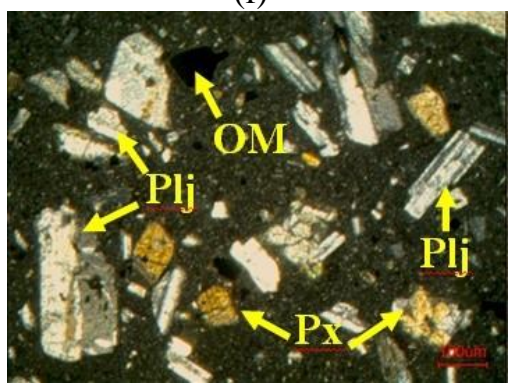

(h)

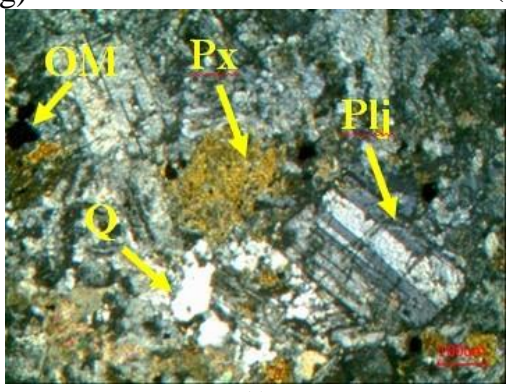

(1)

Şekil 5: Örneklerin polarizan mikroskobu altındaki görünümü

a) $\mathrm{BC}$, b) $\mathrm{BBO}$, c) $\mathrm{BBI}$, d) BTM, e) BTH, f) BK, g) BE, h) BD, 1) BI

(Px: Piroksen, Plj: Plajiyoklas, Ol: Olivin, OM: Opak Mineral, Bio: Biyotit) (Çift Nikol. 4X) 
Tablo 2. Modal analiz sonuçlarına göre elde edilen mineral yüzdeleri

\begin{tabular}{|l|c|c|c|c|c|c|c|c|}
\hline \multirow{2}{*}{$\begin{array}{l}\text { Örnek } \\
\text { Kodu }\end{array}$} & \multicolumn{9}{|c|}{ Modal mineral yüzdesi (\%) } \\
\cline { 2 - 10 } & Hamur & Piroksen & Plajiyoklas & Olivin & $\begin{array}{c}\text { Ayrışmış } \\
\text { mineral }\end{array}$ & Kuvars & Biyotit & $\begin{array}{c}\text { Opak } \\
\text { Min. }\end{array}$ \\
\hline BBO & 69.34 & 10.89 & 19.29 & - & - & - & - & 0.48 \\
\hline BC & 56.35 & 14.22 & 25.86 & - & 1.33 & - & - & 2.24 \\
\hline BD & 61.14 & 13.89 & 23.00 & - & 0.85 & - & - & 1.12 \\
\hline BK & 52.42 & 21.29 & 15.62 & - & 9.12 & - & - & 1.55 \\
\hline BTH & 80.13 & 7.00 & 9.24 & 3.51 & - & - & - & 0.12 \\
\hline BTM & 69.91 & 8.29 & 12.57 & 9.01 & - & - & - & 0.22 \\
\hline BBI & 50.79 & 17.45 & 28.09 & - & 1.20 & - & - & 2.47 \\
\hline BI & 55.19 & 15.14 & 25.60 & - & 2.16 & 0.18 & - & 1.73 \\
\hline BE & 46.48 & 27.58 & 17.90 & 1.59 & 2.26 & - & 3.61 & 0.58 \\
\hline
\end{tabular}

Tablo 3. Bazaltik kayaçların ana element oksit yüzdeleri

\begin{tabular}{|l|l|l|l|l|l|l|l|l|}
\hline \multirow{2}{*}{$\begin{array}{l}\text { Örnek } \\
\text { Kodu }\end{array}$} & $\mathrm{SiO}_{2}$ & $\mathrm{Al}_{2} \mathrm{O}_{3}$ & $\mathrm{Fe}_{2} \mathrm{O}_{3}$ & $\mathrm{CaO}$ & $\mathrm{MgO}$ & $\mathrm{SO}_{3}$ & $\mathrm{~K}_{2} \mathrm{O}$ & $\mathrm{Na}_{2} \mathrm{O}$ \\
\hline BBO & 54.28 & 19.93 & 8.96 & 7.70 & 2.76 & 0.16 & 1.12 & 3.51 \\
\hline BC & 56.63 & 18.52 & 5.95 & 6.65 & 3.34 & 0.15 & 3.28 & 3.03 \\
\hline BD & 57.65 & 17.22 & 6.52 & 6.69 & 2.96 & 0.15 & 1.18 & 3.68 \\
\hline BK & 51.73 & 18.32 & 5.87 & 9.08 & 3.09 & 0.15 & 2.39 & 3.31 \\
\hline BTH & 46.33 & 13.67 & 10.96 & 9.79 & 11.63 & 0.15 & 2.31 & 4.52 \\
\hline BTM & 45.14 & 13.25 & 10.19 & 9.08 & 12.11 & 0.16 & 1.90 & 3.04 \\
\hline BBI & 57.13 & 17.75 & 6.96 & 6.75 & 3.81 & 0.15 & 1.96 & 3.43 \\
\hline BI & 60.15 & 15.13 & 5.49 & 4.98 & 2.86 & 0.63 & 0.56 & 2.97 \\
\hline BE & 49.67 & 12.26 & 7.89 & 7.91 & 12.74 & 0.14 & 5.51 & 2.53 \\
\hline
\end{tabular}

Tablo 4. Laboratuvar çalışmaları kapsamında yapılan karot, agrega deneyleri ve ilgili standartlar

\begin{tabular}{|l|l|}
\hline Özellik & Deney Metodu \\
\hline Tane büyüklüğü dağılımı & TS EN 933-1 (1999) \\
\hline İnce malzeme içeriği & TS EN 933-1 (1999) \\
\hline Çok ince malzeme içeriği & TS EN 933-1 (1999) \\
\hline Yassılık endeksi & TS EN 933-3 (1999) \\
\hline Tane uzunluğu & TS EN 933-4 (2001) \\
\hline Su emme & TS EN 1097-6 (2002) \\
\hline Tane yoğunluğu & TS EN 1097-6 (1999) \\
\hline Los Angeles aşınma & TS EN 1097-2 (2010) \\
\hline Micro-Deval aşınma & TS EN 1097-1 (2006) \\
\hline Magnezyum sülfat $\left(\mathrm{MgSO}_{4}\right)$ değeri & TS EN 1367-2 (2011) \\
\hline Tek eksenli basınç dayanımı & TS EN 1926 (2000) \\
\hline
\end{tabular}


Tablo 5. Çalışma kapsamında kullanılan agregalar üzerinde yapılan fiziksel deneyler

\begin{tabular}{|c|c|c|c|c|c|c|}
\hline $\begin{array}{c}\text { Örnek } \\
\text { kodu }\end{array}$ & $\begin{array}{c}\text { İnce malzeme } \\
\text { içeriği (\%) }\end{array}$ & $\begin{array}{c}\text { Çok ince } \\
\text { malzeme } \\
\text { içeriği (\%) }\end{array}$ & $\begin{array}{c}\text { Yassillk } \\
\text { endeksi }(\%)\end{array}$ & $\begin{array}{c}\text { Tane uzunluğu } \\
(\%)\end{array}$ & $\begin{array}{c}\text { Su emme } \\
(\%)\end{array}$ & $\begin{array}{c}\text { Tane yoğunluğu } \\
\left(\mathrm{Mg} / \mathrm{m}^{3}\right)\end{array}$ \\
\hline BBO & 0.07 & 0.03 & 19.0 & 0.9 & 0.22 & 2.71 \\
\hline BC & 0.10 & 0.05 & 13.2 & 12.0 & 0.24 & 2.66 \\
\hline BD & 0.05 & 0.00 & 16.5 & 2.1 & 0.17 & 2.68 \\
\hline BK & 0.08 & 0.02 & 8.1 & 0.0 & 0.45 & 2.68 \\
\hline BTH & 0.27 & 0.15 & 21.4 & 5.2 & 0.30 & 2.77 \\
\hline BTM & 0.10 & 0.03 & 17.2 & 3.8 & 0.15 & 2.76 \\
\hline BBI & 0.50 & 0.41 & 10.4 & 5.3 & 0.21 & 2.69 \\
\hline BI & 0.45 & 0.04 & 11.2 & 7.2 & 0.22 & 2.70 \\
\hline BE & 0.27 & 0.03 & 5.4 & 0.0 & 0.42 & 2.73 \\
\hline
\end{tabular}

Tablo 6. Çalışma kapsamında kullanılan agregalar ve karotlar üzerinde yapılan mekanik deneyler

\begin{tabular}{|c|c|c|c|c|}
\hline Örnek kodu & $\begin{array}{c}\text { Los Angeles katsayıs1 } \\
(\%)\end{array}$ & $\begin{array}{c}\text { Micro-Deval } \\
\text { katsayısı (\%) }\end{array}$ & $\mathrm{MgSO}_{4}$ değeri (\%) & $\begin{array}{c}\text { Basıç dayanımı } \\
(\mathrm{MPa})\end{array}$ \\
\hline BBO & 11 & 7 & 1.53 & 205 \\
\hline BC & 14 & 9 & 0.72 & 195 \\
\hline BD & 11 & 5 & 0.60 & 206 \\
\hline BK & 12 & 11 & 1.84 & 216 \\
\hline BTH & 9 & 7 & 1.31 & 288 \\
\hline BTM & 8 & 8 & 2.6 & 193 \\
\hline BBI & 12 & 8 & 0.73 & 165 \\
\hline BI & 13 & 10 & 1.38 & 195 \\
\hline BE & 9 & 13 & 1.32 & \\
\hline
\end{tabular}

Tablo 7. Bazaltik agregaların tane büyüklüğü dağılımları

\begin{tabular}{|c|c|c|c|c|c|c|c|c|c|c|c|}
\hline \multirow{2}{*}{ Elek açıklığ $(\mathrm{mm})$} & BBO & BC & BD & BK & BTH & BTM & BBI & \multicolumn{2}{|c|}{ BI } & BE \\
\cline { 2 - 13 } & \multicolumn{9}{|c|}{ \% Geçen } \\
\hline 80 & 100 & 100 & 100 & 100 & 100 & 100 & 100 & 100 & 100 \\
\hline 63 & 94.83 & 92.73 & 99.39 & 99.50 & 98.22 & 100 & 99.02 & 100 & 100 \\
\hline 50 & 54.97 & 55.07 & 81.84 & 82.27 & 77.50 & 82.34 & 73.77 & 56.75 & 87.35 \\
\hline 40 & 25.01 & 21.79 & 45.47 & 48.71 & 47.35 & 57.03 & 23.75 & 9.42 & 64.46 \\
\hline 31.5 & 9.00 & 5.51 & 18.19 & 21.73 & 21.73 & 26.28 & 2.75 & 3.90 & 30.69 \\
\hline 22.4 & 0.92 & 0.50 & 0.60 & 0.35 & 3.59 & 0.71 & 0.52 & 0.47 & 1.11 \\
\hline 0.5 & 0.07 & 0.10 & 0.05 & 0.08 & 0.27 & 0.10 & 0.50 & 0.45 & 0.27 \\
\hline 0.063 & 0.03 & 0.05 & 0 & 0.02 & 0.15 & 0.03 & 0.41 & 0.04 & 0.03 \\
\hline
\end{tabular}

Tablo 8. 1000, 2000 ve 3000 devir Los Angeles aşınma test sonuçları

\begin{tabular}{|l|l|c|c|c|c|c|c|c|c|c|}
\hline Deney adı & BBO & BC & BD & BK & BTH & BTM & BBI & BI & BE \\
\hline $\begin{array}{l}\text { Los Angeles } \\
\text { katsayis1 } \\
(\%)\end{array}$ & 1000 devir & 11 & 14 & 11 & 12 & 9 & 8 & 12 & 13 & 9 \\
\cline { 2 - 11 } & 2000 devir & 19 & 23 & 17 & 20 & 14 & 13 & 20 & 19 & 15 \\
\cline { 2 - 11 } & 3000 devir & 24 & 30 & 24 & 27 & 19 & 17 & 26 & 23 & 21 \\
\hline
\end{tabular}


Tablo 9. İlksel (saha çalışmalarından getirilen balastlar üzerinde) ve 3000 devir Los Angeles cihazında çevrilip yıpratıldıktan/aşındırıldıktan sonra yapılan magnezyum sülfat test sonuçları

\begin{tabular}{|l|c|c|c|c|c|c|c|c|c|}
\hline Deney adi & BBO & BC & BD & BK & BTH & BTM & BBI & BI & BE \\
\hline$* \mathrm{MgSO}_{4}$ değeri (\%) & 1.53 & 0.72 & 0.60 & 1.84 & 1.31 & 2.60 & 0.73 & 1.38 & 1.32 \\
\hline $\begin{array}{l}\text { Los Angeles katsayı1s1 } \\
\begin{array}{l}3000 \text { devir) + } \\
\mathrm{MgSO}_{4} \text { değeri (\%) }\end{array}\end{array}$ & 2.95 & 0.92 & 0.65 & 3.30 & 1.68 & 2.77 & 1.62 & 3.95 & 2.28 \\
\hline
\end{tabular}

* Tablo 6'dan alınmıştır.

Tablo 10. Bazaltik kayaçların mikro çatlak özellikleri

\begin{tabular}{|c|c|c|c|c|c|c|c|c|c|}
\hline Numune & BBO & BC & BD & BK & BTH & BTM & BBI & BI & BE \\
\hline ilksel & - & $2308 \mu \mathrm{m}$ & $2393 \mu \mathrm{m}$ & - & $3510 \mu \mathrm{m}$ & - & - & - & $1764 \mu \mathrm{m}$ \\
\hline $\begin{array}{c}1000 \text { devir } \\
\text { Los Angeles }\end{array}$ & - & $730 \mu \mathrm{m}$ & $568 \mu \mathrm{m}$ & - & $3415 \mu \mathrm{m}$ & - & $2274 \mu \mathrm{m}$ & - & $3248 \mu \mathrm{m}$ \\
\hline $\begin{array}{c}2000 \text { devir } \\
\text { Los Angeles }\end{array}$ & - & $263 \mu \mathrm{m}$ & $6555 \mu \mathrm{m}$ & $1728 \mu \mathrm{m}$ & $2869 \mu \mathrm{m}$ & $815 \mu \mathrm{m}$ & $2149 \mu \mathrm{m}$ & - & $4436 \mu \mathrm{m}$ \\
\hline $\begin{array}{c}3000 \text { devir } \\
\text { Los Angeles }\end{array}$ & - & - & $2315 \mu \mathrm{m}$ & - & $3665 \mu \mathrm{m}$ & $1292 \mu \mathrm{m}$ & $5037 \mu \mathrm{m}$ & - & $3459 \mu \mathrm{m}$ \\
\hline $\begin{array}{c}\text { ilksel } \\
\left(\mathrm{MgSO}_{4}\right)\end{array}$ & $338 \mu \mathrm{m}$ & $2914 \mu \mathrm{m}$ & $2276 \mu \mathrm{m}$ & $2133 \mu \mathrm{m}$ & $1207 \mu \mathrm{m}$ & $2093 \mu \mathrm{m}$ & $2905 \mu \mathrm{m}$ & - & $6212 \mu \mathrm{m}$ \\
\hline $\begin{array}{c}3000 \text { devir } \\
\text { Los Angeles } \\
+ \text { MgSO }_{4}\end{array}$ & $711 \mu \mathrm{m}$ & $2573 \mu \mathrm{m}$ & $4883 \mu \mathrm{m}$ & $4366 \mu \mathrm{m}$ & $1234 \mu \mathrm{m}$ & $3923 \mu \mathrm{m}$ & $2287 \mu \mathrm{m}$ & - & $5756 \mu \mathrm{m}$ \\
\hline
\end{tabular}

(-): Mikro çatlak tespit edilemeyen kesitlere ait örnekler.

\section{BULGULAR DEĞERLENDİIILMESİ}

Arıoğlu vd. [1]'de belirttiği gibi, ulusal ve uluslararası demiryolu balast şartname değerleri dikkate alındığında (Tablo 11), bu çalışma kapsamında kullanılan tüm bazaltik kayaçlardan üretilmiş balastlar her türlü demiryolu uygulamaları için belirtilen şartname değerlerini sağlamaktadır. Bu durum örneklerin bileşiminde bulunan az miktarda ayrışmış mineral yüzdesinden bir başka deyişle örneklerin ayrışmamış (taze) olmalarından kaynaklanmaktadır. Örneklerin ayrışmamış olması bu örneklerin yükssek dayanım ve dayanıklılık özelliklerine sahip olmasını da sağlamaktadır.

Çalışma kapsamında kullanılan balast örneklerinin üzerinde yapılmış 1000, 2000 ve 3000 devir Los Angeles testlerinin sonuçları ile aynı balastların tane yoğunluklarının karşılaştırılması Şekil 6'da sunulmuştur. Buna göre, balast örneklerinin tane yoğunlukları artıkça Los Angeles aşınma katsayıları azalmakta yani balastlar (devir sayısı artsa bile) aşınmaya/yıpranmaya karşı dayanım kazanmaktadırlar. Buna ilaveten, özellikle BTH ve BTM kodlu örnekler diğerlerine göre daha yüksek tane yoğunluğuna ve dolayısıyla da daha düşük Los Angeles aşınma katsayısına sahiptirler. Bu durumun, ilgili iki örneğin de hamur ve olivin içeriklerinin yüksek yüzdeye sahip olmasından kaynaklandığı şeklinde yorumlanmıştır. 
Tablo 11. Ulusal ve bazı uluslararası demiryolu balast şartname değerleri [1]

\begin{tabular}{|c|c|c|c|c|c|c|}
\hline \multirow[b]{2}{*}{ Balast özelliği } & \multirow[b]{2}{*}{ Avustralya } & \multirow[b]{2}{*}{ Amerika } & \multirow[b]{2}{*}{ Kanada } & \multicolumn{2}{|c|}{ İspanya } & \multirow[b]{2}{*}{ Türkiye } \\
\hline & & & & $\begin{array}{c}>4000 / \mathrm{t} \\
\text { gün } \mathrm{A} \\
\text { balast } \sigma_{\mathrm{b}, \mathrm{lab}} \\
\geq 120 \mathrm{MPa}\end{array}$ & $\begin{array}{c}>4000 / \text { t gün } \\
\mathrm{B} \text { balast } \\
\sigma_{\mathrm{b}, \mathrm{lab}} \geq 100 \\
\mathrm{MPa}\end{array}$ & \\
\hline $\begin{array}{c}\text { Los Angeles } \\
\text { katsayis } 1\end{array}$ & $<\% 25$ & $<\% 40$ & $<\% 20$ & $\leq \% 19-\% 22$ & $\leq \% 26$ & $\leq \% 15$ \\
\hline $\begin{array}{l}\text { Yassılık } \\
\text { endeksi }\end{array}$ & $<\% 30$ & - & - & - & - & $\leq \% 20$ \\
\hline $\begin{array}{c}\text { Tane } \\
\text { Uzunluğu }\end{array}$ & $<\% 30$ & - & $<\% 25$ & - & - & $\leq \% 25$ \\
\hline $\mathrm{MgSO}_{4}$ değeri & - & - & $<\% 10$ & $\% 8$ & $\% 8$ & $\leq \% 5$ \\
\hline $\begin{array}{l}\text { İnce malzeme } \\
\text { içeriğ } i\end{array}$ & - & $<\% 1$ & $<\% 1$ & - & - & $\begin{array}{c}0.5 \mathrm{~mm} \text { elek } \\
\leq \% 0.6 \\
\% 0.063 \mathrm{~mm} \text { elek } \\
\leq \% 0.5\end{array}$ \\
\hline $\begin{array}{c}\text { Tane } \\
\text { yoğunluğu }\end{array}$ & $>2.5$ & - & $>2.6$ & - & - & - \\
\hline
\end{tabular}

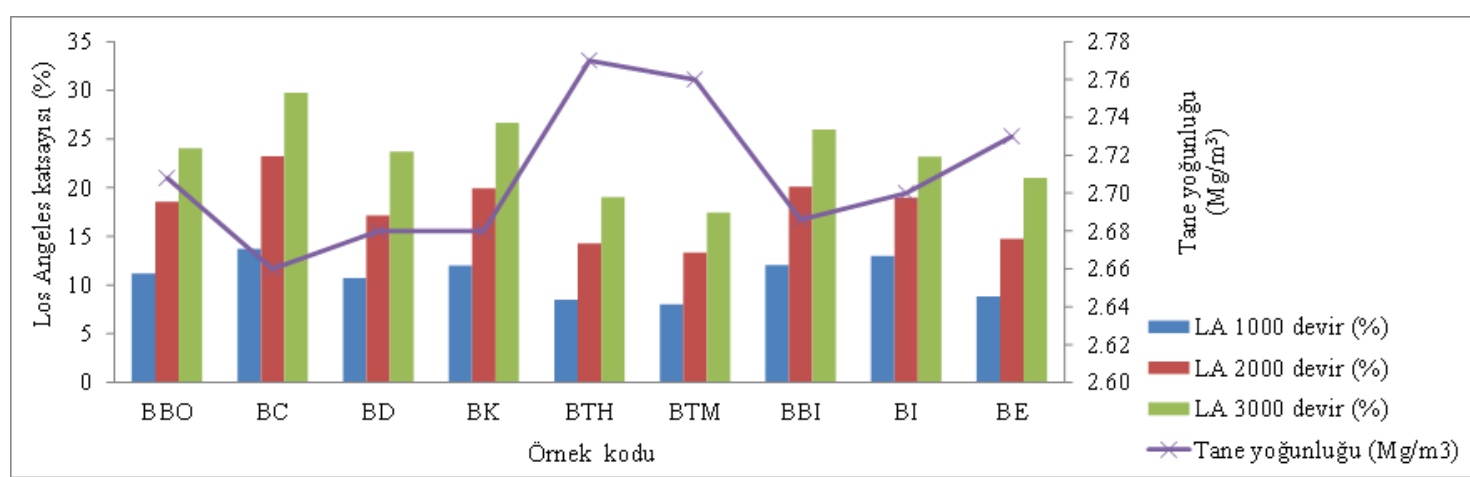

Şekil 6. 1000, 2000 ve 3000 devir Los Angeles test sonuçları ile tane yoğunluklarının karşılaştırılması

Micro-Deval, magnezyum sülfat ve 3000 devir çevrim yapılan Los Angeles aşınma testi sonrasında aynı örnekler üzerinde yapılan magnezyum sülfat test sonuçlarına göre (Tablo 6, 8 ve 9), bu çalışmada kullanılan bazaltlar yüksek dayanıma ve dayanıklılığa sahip olup, bu kayaçların demiryolunda balast olarak kullanılmaları durumunda servis ömürleri süresince minimum düzeyde balast kirlenmesine neden olacaktırlar. Bu durum kayaçların bileşiminde bulunan çok düşük miktardaki ayrışmış mineral içeriğine ve kayaçların düşük su emme değerlerine sahip olmalarına bağlı olduğu düşünülmüştür (Tablo 2 ve 5).

Agregaların parçalanma özelliklerini ortaya koymak için kullanılan en etkili yöntem, Los Angeles aşınma testidir. Bu test, demiryollarında kullanılan balastın servis ömrü süresince tren yükünden nasıl etkilendiğini ortaya koymak için kullanılan pratik ve etkili bir testtir $[10,11]$. Bu durum çalışmadaki tüm Los Angeles test sonuçlarında da gözlenmiştir. Çalışma kapsamında kullanılan bazalt agregalarının Los Angeles aşınma katsayıları, devir sayısı arttıkça, artmakta, bir başka deyişle, devir sayısı arttıkça balast parçalanması da artmaktadır (Tablo 8). Özetle, tren yükü altında balast üzerinde biriken bu stres, balastların parçalanmasına yetecek kadar gerilmelerin oluşmasına neden olmaktadır.

Daha önce bir çok araştırmacı kayaçların kimyasal içeriklerini baz alarak çeşitli indeksler geliştirmiştir (Tablo 12). Bu çalışmada kullanılan bazaltların petrografik ve kimyasal özelliklerinin, balast kirlenmesine etkilerini ortaya koymak için, bazalt agregalarının petrografik ve kimyasal bileşimleri ile dayanım özellikleri 
karşılaştırılmıştır. Bunun için, bu çalışmada bazalt agregaları için yeni bir petrografik indeks tanımlanmıştır. Bu indeks aşağıdaki formül ile gösterilmiştir;

$$
\begin{array}{ll}
\mathrm{PI}=\mathrm{H} /(\mathrm{Px}+\mathrm{Pl}+\mathrm{Om}) \\
\mathrm{PI}= & \text { petrografik indeks } \\
\mathrm{H}= & \text { hamur yüzdesi } \\
\mathrm{Px}= & \text { piroksen yüzdesi } \\
\mathrm{Pl}= & \text { plajiyoklas yüzdesi } \\
\mathrm{Om}= & \text { opak mineral yüzdesi }
\end{array}
$$

Çalışma kapsamında kullanılan bazaltların mineral bileşimleri kullanılarak ve yukarıda tanımlanan petrografik indeks formülüne göre her bir örneğin petrografik indeks değerleri hesaplanmıştır (Tablo 13). Elde edilen bu indeks ile Los Angeles aşınma katsayıları (1000, 2000 ve 3000 devir) karşılaştırıldığında, petrografik indeks arttıkça Los Angeles aşınma katsayıları azalmaktadır (Şekil 7). Bunun dışında, basit regresyon analizi yardımıyla, kimyasal indeksler ile Los Angeles aşınma katsayıları (1000, 2000 ve 3000 devir) karşıllaştırılmıştır. Analizlerden elde edilen ilişkiler ve korelasyon katsayıları Şekil 8'de sunulmuştur. Buna göre, bazalt agregalarının Los Angeles aşınma katsayıları ile Vogt oranı arasında oldukça yüksek korelasyon katsayısına sahip doğrusal bir ilişki belirlenmiştir. Buna ilave olarak, Vogt oranı ile kimyasal alterasyon indeksi arttıkça ve değiştirilmiş ayrışma potansiyeli indeksi azaldıkça, Los Angeles aşınma katsayısı değerleri artmakta bir başka değişle agregalar daha fazla aşınma/parçalanmaya uğramaktadırlar (Şekil 8a, 8b ve 8c).

Tablo 12. Daha önceki çalışmalarda önerilen bazı kimyasal indeks formülleri

\begin{tabular}{|l|c|}
\hline İndeks adı & Formül \\
\hline Vogt oranı, VR [12, 13] & $\frac{\mathrm{Al}_{2} \mathrm{O}_{3}+\mathrm{K}_{2} \mathrm{O}}{\mathrm{MgO}+\mathrm{CaO}+\mathrm{Na}_{2} \mathrm{O}}$ \\
\hline $\begin{array}{l}\text { Değiștirilmiş ayrışma potansiyeli } \\
\text { indeksi, MWPI [14] }\end{array}$ & {$\left[\mathrm{Na}_{2} \mathrm{O}+\mathrm{K}_{2} \mathrm{O}+\mathrm{CaO}+\mathrm{MgO}\right] \times 100$} \\
\hline Kimyasal alterasyon indeksi, CIA [15] & {$\left[\mathrm{Na}_{2} \mathrm{O}+\mathrm{K}_{2} \mathrm{O}+\mathrm{CaO}+\mathrm{MgO}+\mathrm{SiO}_{2}+\mathrm{Al}_{2} \mathrm{O}_{3}+\mathrm{Fe}_{2} \mathrm{O}_{3}\right]$} \\
\hline & $\frac{\mathrm{Al}_{2} \mathrm{O}_{3} x 100}{\mathrm{Al}_{2} \mathrm{O}_{3}+\mathrm{CaO}+\mathrm{Na}_{2} \mathrm{O}+\mathrm{K}_{2} \mathrm{O}}$ \\
\hline
\end{tabular}

Tablo 13. Bazaltik agregaların petrografik ve kimyasal indeks değerleri

\begin{tabular}{|l|c|c|c|c|}
\hline \multirow{2}{*}{ Örnek kodu } & \multicolumn{4}{|c|}{ Indeks adı } \\
\cline { 2 - 5 } & Petrografik indeks & Vogt oranı & $\begin{array}{c}\text { Değiştirilmiş } \\
\text { ayrışma } \\
\text { potansiyeli } \\
\text { indeksi }\end{array}$ & $\begin{array}{c}\text { Kimyasal } \\
\text { alterasyon } \\
\text { indeksi }\end{array}$ \\
\hline BBO & 2.23 & 1.51 & 15.36 & 61.78 \\
\hline BC & 1.36 & 1.67 & 16.74 & 58.83 \\
\hline BD & 1.60 & 1.38 & 15.13 & 59.85 \\
\hline BK & 1.37 & 1.34 & 19.05 & 55.35 \\
\hline BTH & 3.78 & 0.62 & 28.47 & 45.13 \\
\hline BTM & 3.31 & 0.63 & 27.59 & 48.59 \\
\hline BBI & 1.05 & 1.41 & 16.31 & 59.38 \\
\hline BI & 1.28 & 1.45 & 12.34 & 64.00 \\
\hline BE & 1.01 & 0.77 & 29.12 & 43.46 \\
\hline
\end{tabular}




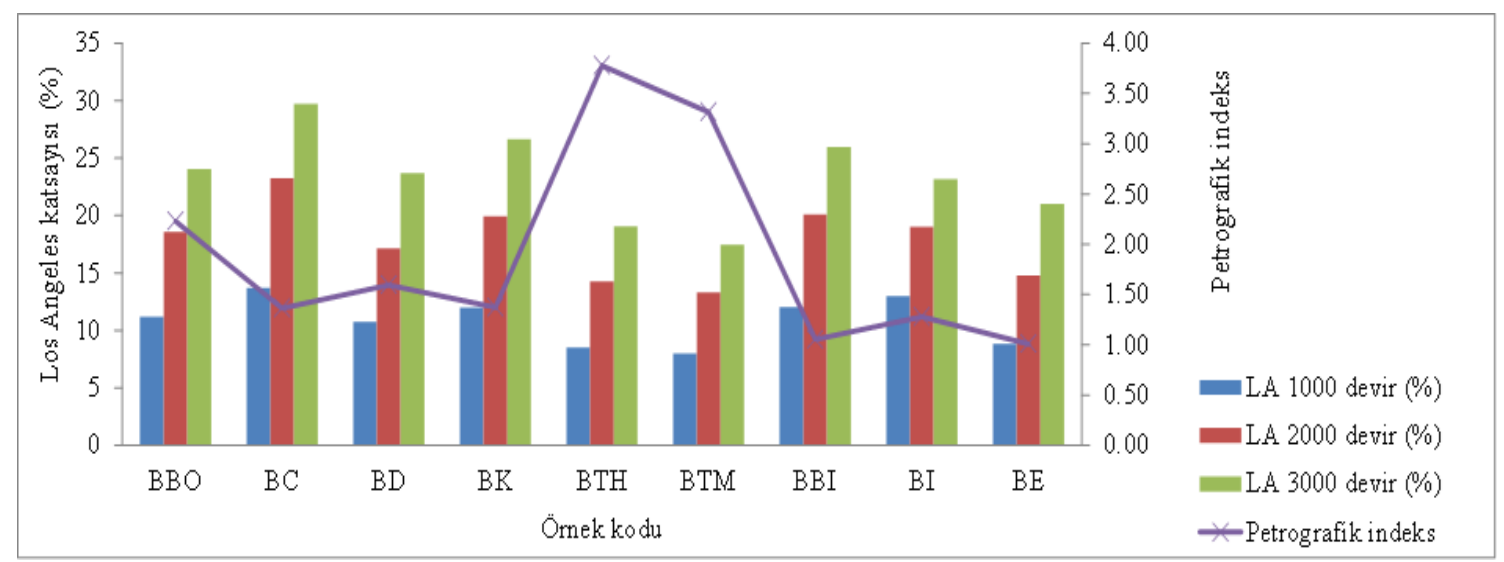

(a)

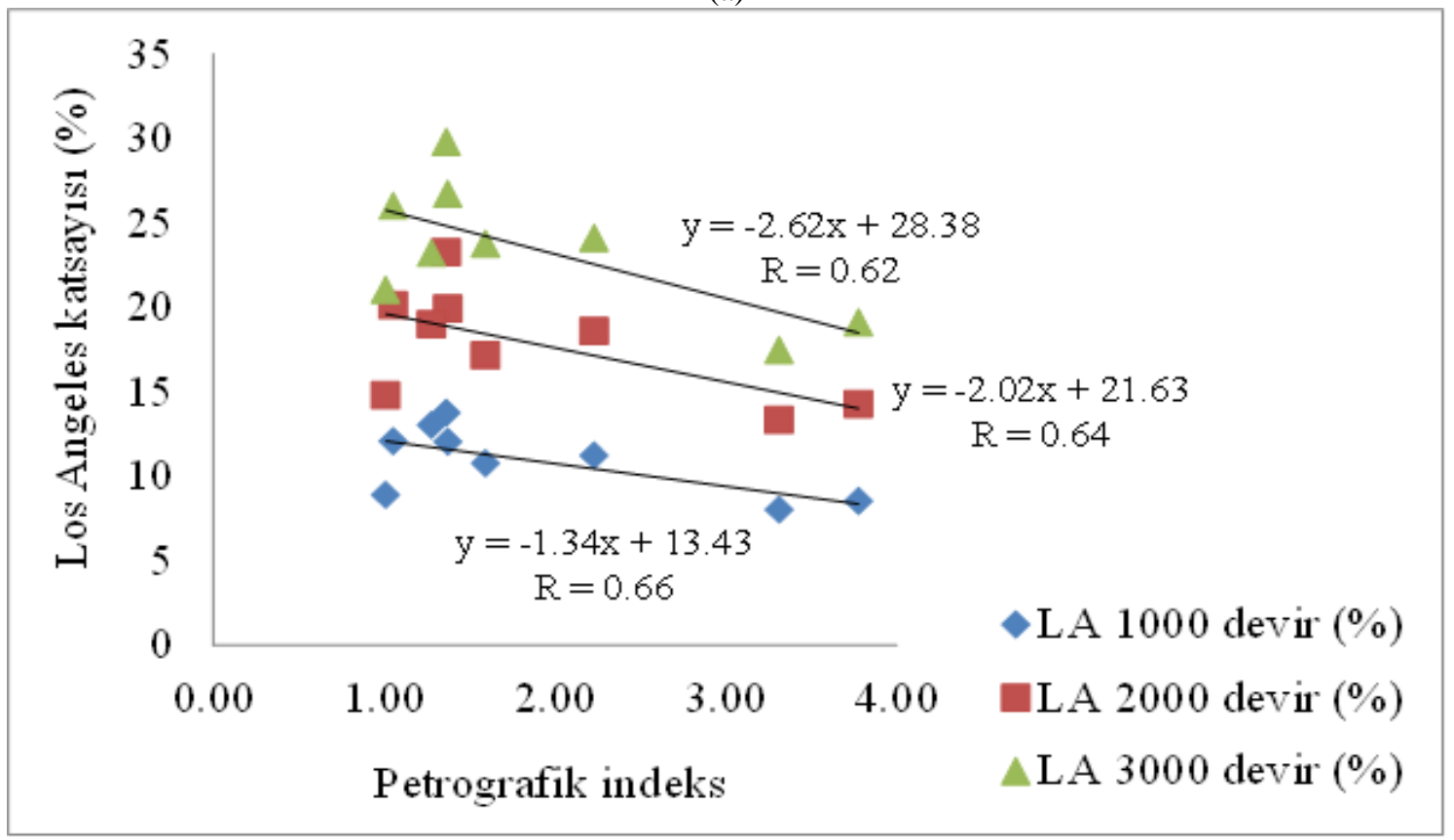

(b)

Şekil 7. (a) Petrografik indeks ile Los Angeles aşınma katsayılarının karşılaştırılması, (b) Petrografik indeks ile Los Angeles aşınma katsayılarının basit regresyon analizi ile karşılaştırılması 


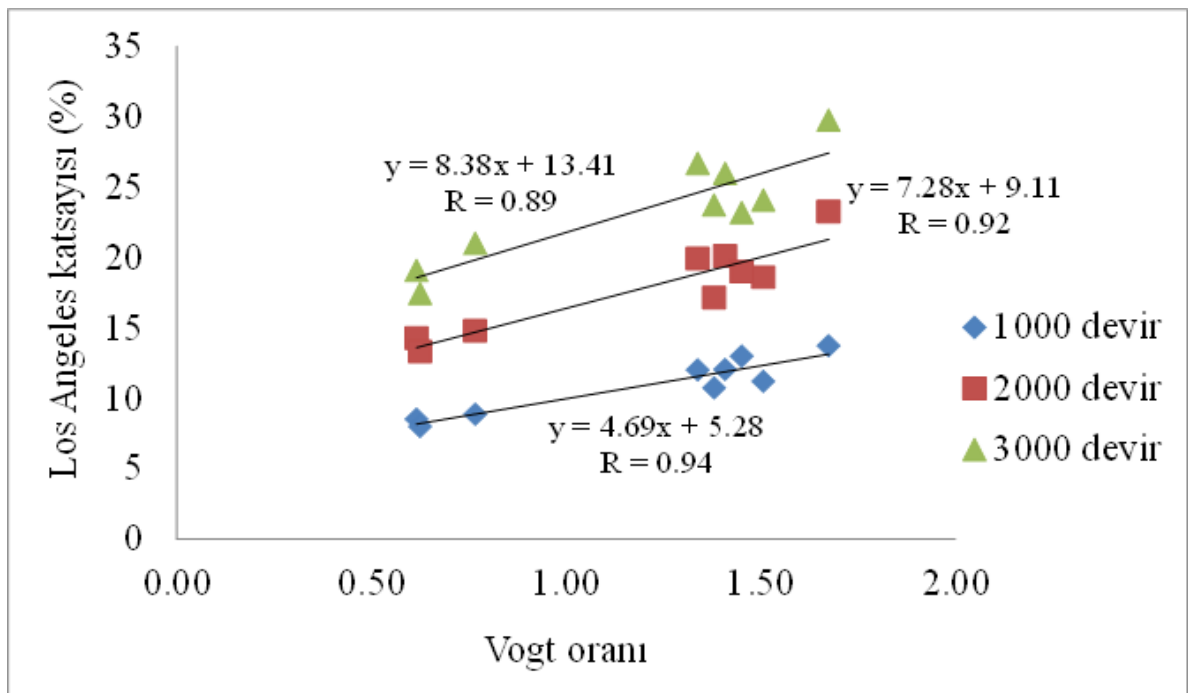

(a)

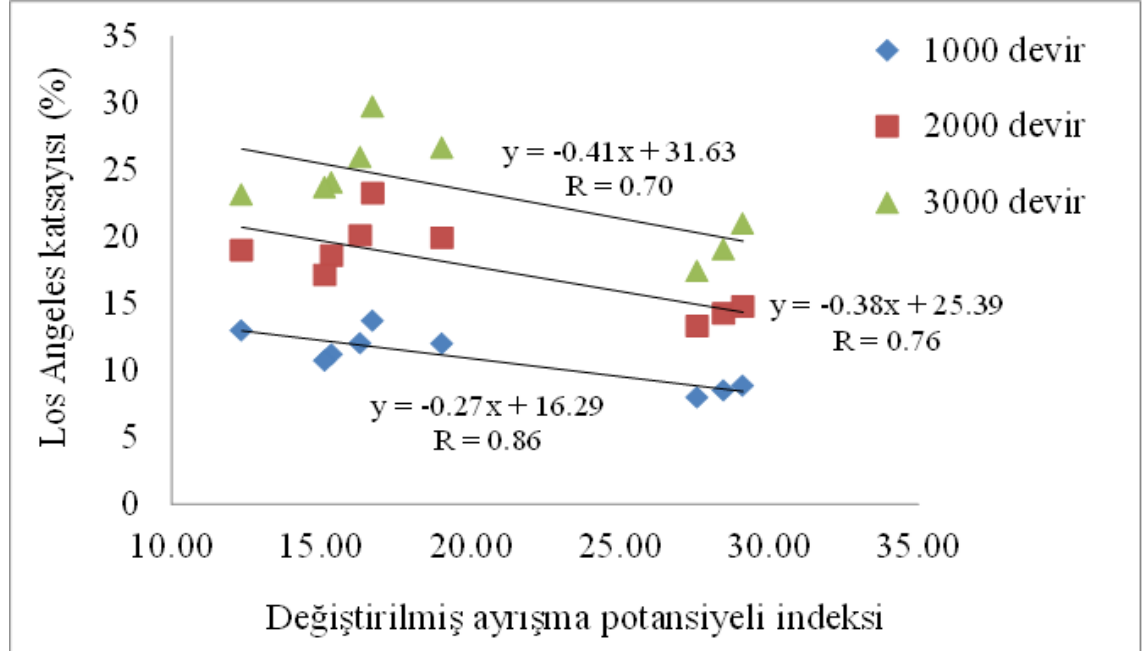

(b)

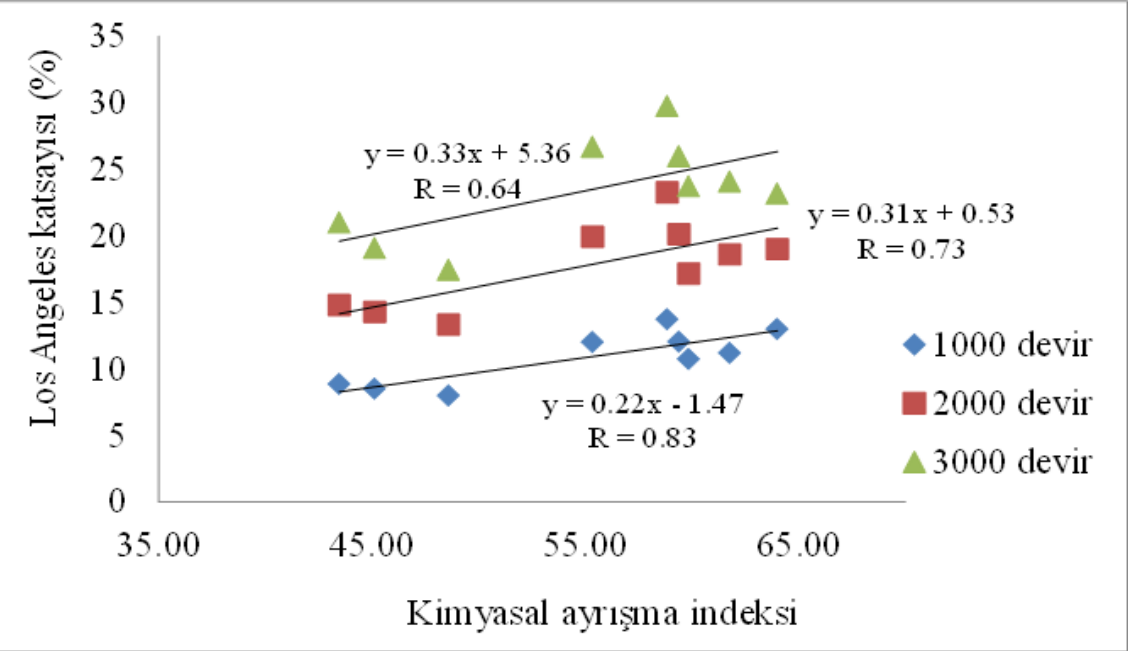

(c) 


\section{Ö.F. APAYDIN, M. YILMAZ}

Şekil 8. Los Angeles aşınma katsayıları (1000, 2000 ve 3000 devir) ile kimyasal indeksler (a) Vogt oranı, (b) değiştirilmiş ayrışma potansiyeli indeksi, (c) kimyasal alterasyon indeksi arasındaki ilişkilerin karşılaştırılması

Agregaların mekanik parçalanma özelliklerini belirlemek için kullanılan test yöntemlerinden bir diğeri de Micro-Deval aşınma testidir. Bu test, sulu bir ortamda agrega tanelerinin birbirlerini aşındırmaya uğratması ve agregaların aşınmaya karşı göstermiş oldukları direnci belirlemek için yapılmaktadır [10]. Çalışma kapsamında yapılan Micro-Deval test sonuçlarına göre, bazaltik agregalardan birbirlerine yakın Micro-Deval katsayıları elde edilmiştir (Tablo 14). Ancak bu katsayılar basit regresyon yöntemi aynı agregalara ait petrografik ve kimyasal indekslerle karşılaştırıldığında, bu parametreler arasında kabul edilebilir anlamlılık düzeyinde herhangi bir ilişki belirlenememiştir (Tablo 14).

Tablo 14. Agregaların dayanım ve dayanıklılık test sonuçları ile indeksler arasında belirlenen korelasyon katsayıları (R)

\begin{tabular}{|l|c|c|c|c|}
\hline \multirow{2}{*}{ Örnek kodu } & \multicolumn{3}{|c|}{ Indeks adı } \\
\cline { 2 - 5 } & Petrografik indeks & Vogt oranı & $\begin{array}{c}\text { Değiştirilmiş ayrışma } \\
\text { potansiyeli indeksi }\end{array}$ & $\begin{array}{c}\text { Kimyasal alterasyon } \\
\text { indeksi }\end{array}$ \\
\hline $\begin{array}{l}\text { Micro-Deval } \\
\text { katsayıs1 }\end{array}$ & -0.46 & -0.14 & 0.29 & 0.34 \\
\hline $\mathrm{MgSO}_{4}$ değeri & +0.51 & -0.54 & 0.46 & -0.38 \\
\hline $\begin{array}{l}\text { Los Angeles testi } \\
(3000 \text { devir) sonras1 } \\
\begin{array}{l}\text { yap1lan MgSO } \\
\text { sonucu (\%) }\end{array}\end{array}$ & - & -0.07 & -0.06 & 0.10 \\
\hline
\end{tabular}

İklim koşullarındaki değişimler, demiryolu balastlarının servis ömürleri süresince parçalanmasına neden olmaktadır. Bu iklim koşullarının (donma-çözünm) balastlar üzerindeki etkileri belirlemek amacı ile durabilite (dayanıklılık) testleri yapılmaktadır. Magnezyum sülfat testi balastların donma-çözünme özellikleri belirlemede yaygınca kullanılan bir metottur [2]. Bu çalışmada bazaltik agregalar üzerinde yapılan magnezyum sülfat test sonuçları değerlendirildiğinde, petrografik ve kimyasal indeksler ile magnezyum sülfat değerleri arasında anlamlı bir ilişki belirlenememiştir (Tablo 14). Buna ilaveten, balast kirliliği açısından tren yüklerinden kaynaklanan dinamik yüklerin ve iklimsel koşulların etkilerini ortaya koyabilmek için 3000 devir Los Angeles aşınma testi sonrası çıkan balast örnekleri üzerinde magnezyum sülfat testleri yapılmıştır (Tablo 9). Elde edilen sonuçlara göre, petrografik ve kimyasal indeksler ile 3000 devir Los Angeles testi sonrası yapılan magnezyum sülfat testinden elde edilen sonuçlar arasında da anlamlı bir ilişki belirlenememiştir (Tablo 14).

\section{SONUÇLAR}

Bu araştırmada, Türkiye'nin çeşitli bölgelerinden alınan farklı özelliklere sahip bazaltik kayaçların balast agregası olarak kullanılabilirlikleri ve balast kirlenmesi yönünden karşılaştırılması nedenleri ile birlikte ortaya konulmaya çalışılmıştır. Elde edilen sonuçlar aşağıda özetle verilmiştir.

$\mathrm{Bu}$ çalışmada kullanılan bazaltik kayaçlar, yüksek dayanım ve dayanıklılık özelliklerinden dolayı ayrışmamış veya çok az ayrışmış olan bazaltik agregalar, balast olarak kullanılmaları durumunda, hızlı tren projeleri de dahil olmak üzere her türlü demiryolu projesinde, demir yollarının servis ömrü süresince herhangi bir şekilde balast kirlenmesine neden olmayacakları belirlenmiştir. Buna ek olarak, elde edilen sonuçlar ayrıntılı olarak değerlendirildiğinde, bileşiminde yüksek hamur ve olivin yüzdesine sahip olan bazaltik agregalar, diğer bazaltik agregalara göre daha yüksek dayanımlı oldukları belirlenmiştir.

Bu çalışmada bazaltik agregalar için ilk defa tanımlanmış olan bir petrografik indeks ve literatürde yaygınca kullanılan bazı kimyasal indeksler, bazalt kirlenmesi açısından değerlendirmek için kullanılabilecek önemli parametreler olarak belirlenmiştir. Ancak petrografik indeks ile kimyasal indeksleri kendi içlerinde 
kıyaslandığında, kimyasal indeksler, özellikle Vogt oranı, bu çalışmada tanımlanan petrografik indekse göre daha anlamlı sonuçlar vermiştir.

Bazaltik agregalar üzerinde farklı devir sayılarında Los Angeles ve MgSO4 testleri yapılmış ve agregaların bünyesinde gelişen mikro çatlak özellikleri belirlenmiştir. Elde edilen sonuçlara göre, dinamik yükler ve iklimsel koşullar altında ayrışmamış bazaltik agregalarda düzenli bir mikro çatlak gelişimi tespit edilememiştir. Bundan dolayı bazaltik agregaların bünyesinde bulunan veya gelişen mikro çatlaklar, balast kirlenmesine neden olmayacağı düşünülmektedir.

\section{KAYNAKLAR}

[1] AROĞLU, E., KURT, G., YOLDAŞ, R., YALÇIN, H., "Kimi Kayaçların Çok Yüksek Devirli (>500) Los Angeles Aşınma Değerleri”, 5. Ulusal Kırmataş Sempozyumu Bildiriler Kitabı, s.93-101, İstanbul, 2009.

[2] MCNALLY, G.H., Soil and Rock Construction Materials, E and FN Spon, First published, s. 403, London and New York, 1998.

[3] SCHILling, R., "Ballast Cleaning of Single Track Railway Lines: A Strategic Analysis", Rail Engineering International Edition 1; 8-12, 2005.

[4] ROBERTS, R., AL-QADI, I., BOYLE, J., "Railroad Ballast Fouling Detection Using Ground Penetrating Radar - A New Approach Based on Scattering from Voids", ECNDT Th.4.5.1, s.8, 2006.

[5] KNOWN, H.B., PARK, C.S., "An Experimental Study on the Relationship between Ballast Flying Phenomenon and Strong Wind under High Speed Train”, Proceedings of 7th World Congress on Railway Research, Montreal, Canada, s.625, 2006.

[6] KORKANÇ, M. AND TUĞRUL, A., "Evaluation of selected basalts from Niğde, Turkey, as source of concrete aggregate", Engineering Geology, 75, 291-307, 2004.

[7] KORKANÇ, M., TUĞRUL, A., "Beton agregası olarak kullanılacak bazaltların alkali-silis reaksiyonu yönünden değerlendirilmesi”, İstanbul Üniversitesi Müh. Fak. Yerbilimleri Dergisi, S.2, 161-169, 2005.

[8] SELIG, E.T., WATERS, J.M., Track geotechnology and substructure management, Thomas Telford Ltd., London, 1994.

[9] ERKAN, Y., Magmatik Petrografi, Jeoloji Mühendisleri Odası Yayınları, Ankara, 2006.

[10] COOLEY, L.A., HUNER, M.H. AND JAMES, R.S., "Micro-Deval Testing of Aggregates in the Southeast. National Center for Asphalt Technology Report 2002-09”, Auburn University, Alabama, 2002.

[11]LIM, W.L., MCDOWELL, G.R., "Discrete Element Modeling of Railway Ballast", Granular Matter, 7;1929, 2005.

[12] Vogt, T., "Sulitjelmefeltets geologiog petrografi”, Norges Geologiske Undersøkelse, 121, 1-560, 1927.

[13] Roaldset, E., "Mineralogy and geochemistry of Quaternary Clays in Numedal Area, Southern Norway", Narsk. Geol. Tidsskr, 52, 335-369, 1972.

[14] Vogel, D.E., "Precambrian weathering in acid meta-volcanic rocks from the Superior Province", Villebond Township, South Central Quebec", Can J Earth Sci 12:2080-2085, 1973.

[15] NESBITT, H.W. AND YOUNG, G.M. "Early Proterozoic climates and plate motions inferred from major element chemistry of lutites", Nature. 299. 715-717, 1982. 